\title{
ETHICAL ISSUES IN COSMETIC SURGERY FOR WOMEN: SELF-ACTUALIZATION OR MANIPULATION?
}

\author{
Nurulfatmi Amzy, Yayah Rukiah \\ Universitas Indraprasta PGRI
}

\begin{abstract}
The technology of plastic surgery has been beneficial to mankind around the world. Plastic surgery can help people to retain and regain the function on some part of the body that was damaged. However, plastic surgery came with a handful of ethical issues. With the ability to alter one's own body, many women sought to use this technology to beautify themselves. This part of technology then later was named as cosmetic surgery. By the reasoning of self-autonomy and free will, a person can easily alter their own physique according to their own will. This paper aimed to analyze this phenomenon based on philosophical thoughts regarding aesthetic purpose where it argued that beauty is a construction of media and society, not a construction that came from within one's self. This paper argued that cosmetic surgery technology preyed upon women and instead of firming the position of selfautonomy and free will; it degrades women as a human of free will. The overapplication of technology will only objectify women and it poses a danger as it can be used as a tool to satisfy certain interests.
\end{abstract}

Keywords: women; technology; plastic surgery; cosmetic surgery; ethical issues

Correspondence author: Nurulfatmi Amzy, nurulfatmiamzy@gmail.com, Indonesia

\section{INTRODUCTION}

The 2004 Lion Air accident in Adi Soemarmo Airport-Solo has become a national concern at the time. This accident happened when the airplane failed to initiate the landing procedures and resulted in a blast of fire that burnt the airplane. Many got burnt and some lost their life in the accident. One of the surviving victims was Laura Lazarus, a flight attendant of Lion Air. Because of this accident, she got burnt scars all over her body. As she wrote in her personal website, this accident crushed her right cheek bones, shredding the flesh, dislocated her right shoulder, and fractured her hips and right leg. She then underwent 17 surgeries including facial surgery, flesh grafting, and cutting and relocating the bones within her body. 
This story shows that the medical technology nowadays has advanced rapidly that it can repair Laura's condition back to green. This medical surgery was categorized as reconstructive surgery, a field of plastic surgery that was done in order to reconstruct the damaged body parts (Goering). The advancement of technology has become indispensable contributions in the life of all mankind. However, how about cosmetic surgery?

Cosmetic surgery is a field of plastic surgery that was done for aesthetic reason (Goering). In other words, it applied medical technology for non-medical issues. One of such cases was dubbed the human Barbie, where a girl named Valeria Lukyanova underwent a cosmetic surgery to change her look to be like a Barbie doll. At this point, the question arises about how is the position of science and technology regarding this matter? Can it be justified if science and technology was used to satisfy such desire? This paper aimed to analyze this phenomenon based on philosophical thoughts regarding aesthetic purpose where it argued that beauty is a construction of media and society, not a construction that came from within one's self

\section{RESEARCH METHOD}

This research is a descriptive-analysis of literature studies, drawing the source of its analysis from the book titled The Case against Perfection by Michael Sandel and a report from Academy of Medical Sciences, the British Academy, the Academy of Engineering, and the Royal Society titled Human Enhancement and the Future Work. This research uses phenomenology philosophy as a method to analyze the case. Phenomenology is a study of phenomenon. It is filed under a radical philosophy for it dismissed all the assumption that contaminates human concrete experience (Adian). With this method, the research focused itself on the reason behind the practice of fashioning the body, in this case the non-medical plastic surgery, of women. By analyzing the fact without restriction to other's assumptions as the characteristics of a phenomenology research, this paper hoped to obtain an in-depth and objective conclusion regarding ethical issues in cosmetic surgery for women.

The paper will be discussed within the ethics philosophy framework. To analyze the non-medical plastic surgery for women within this framework, this research uses Eudamonia theory proposed by Aristotle. This theory centered on the idea of every action done by a person has a motive, and everything was done to achieve happiness (Magnis-Suseno, 13 Model Pendekatan Etika). This research chose Eudamonia theory as a tool of analysis because oftentimes, happiness was referenced as a reason why women underwent this non-medical plastic surgery. However, the question remains whether this happiness is truly the goal of this action. Michael Sandel, an expert on politics, law, and ethics philosophy from Harvard University reject this notion. This is because the practice of fashioning the body is not more than an exaggeration of self-autonomy that is highly viewed in the Western society (Jena). Sandel argued that every procedure of a non-medical plastic surgery for the purpose of fashioning the body is unethical because it is against the value of human existence and life (Sandel). 


\section{Cosmetics Surgery is a Kind of Ethical Issues}

Many people think that Ethics is a kind of ideal system in morality that tell us how to be a good person, the things that can show us what is right and wrong. However, Franz Magnis-Suseno explained Ethics in the different term. In his book, Etika Dasar, he told that Ethics is the thing that could help a man to find the best orientation in life. The aim is to avoid the domino-effect among people in behaving to certain things. Everyone should have a reason in every single step that they take. Following those statements, he explained that Ethics is different from morality. If morality can be defined as an instruction book that tell us how to maintain a motorcycle in a good way, then Ethics tell us about the motorcycles itself (Magnis-Suseno). So, we can decide what the best thing we should do by our very own point of view.

The advancement of technology put us in some complicated choices. How can we use the technology in a good way? Is that too much to depend ourselves to technology? Those following sentences make ethical theory become so much make sense to use in daily life. It can help us to decide on choosing the best choice. The moment we applied ethical theory to daily life issues, it became Applied Ethics.

Applied ethics is the branch of ethics which consist of the analysis of specific, controversial moral issues such as abortion, animal rights, and euthanasia. In recent years applied ethical issues have been subdivided into convenient groups such as medical ethics, business ethics, environmental ethics, sexual ethics and social ethics (Fieser and Dowden).

Cosmetic surgery through its advancement grows so much attention with a huge problematic pros and contras. Many people support the technology because it can help them in a tremendous way, but there were also people who reject the ideas of cosmetic surgery. Thus, the discussion regarding the problems surrounding cosmetic surgery falls under the field of applied ethics.

\section{Gaining Beauty Through Technology}

Cosmetics surgery is a kind of human enhancement. The term "Human enhancement" encompasses a range of approaches that may be used to improve aspects of human function (e.g. memory, hearing, and mobility). This may either be for the purpose of restoring an impaired function to previous or average levels, or to raise function to a level considered to be "beyond the norm" for humans (Human Enhancement and The Future of Work).

"To raise function to a level considered to be 'beyond the norm' for humans," is what differentiate between therapy and enhancement. Therapy was done to repair bodily function to its normal condition while enhancement was done to enhance the normally functioning body parts which usually have no functional problems to address (Bostrom and Roache).

Fashioning the body, manipulating it for aesthetic reason is not a simple matter in the field of ethics. Furthermore, this practice has gained such an upward trend in recent years. Despite its cost - a routine facelift is about $\$ 5700$ - the popularity of cosmetic surgery is on the rise. According to the Society of Plastic Surgeons, between 1992 and 1999, the number of cosmetic surgery procedures performed in the United States and Canada has risen $175 \%$. Several types of surgery have seen even more 
dramatic increase: liposuction has increased $389 \%$ and breast augmentation has increased $413 \%$ (Goering).

Furthermore, fashioning the body in terms of enhancement in the modern era was supported by the advancement in many fields, such as nanotechnology, biotechnology, information technology, and cognitive science (NBIC). NBICs could - it is claimed - enhance human beings with "more" health, "more" intellectual and physical capacities, "more" lifespan, "more" well-being or, in other words, "more everything we want to be" (Menuz et al.).

Following the statement about NBICs could enhance human beings with "more everything we want to be," there comes an implicit meaning in it. Is a human being could control their life? What are they actually wanted to achieve in life? What makes cosmetic surgery become an important thing for a woman? Gaining beauty or reaching beauty standard among social life, perhaps?

By the advancement of technology, everybody can see the image of beauty in all over the world. By then, they can claim that a beautiful woman should fulfill certain criteria. The media have a huge role in this shifting view in the concept of beauty. In many commercials television, the image shown to symbolize beauty is a woman that has a slim body shape, fair skin complexion, and smooth silky hair. But the point is, is that a true beauty? The question remains whether the symbol represent the concept of Beauty to themselves or to others?

Observing this phenomenon, a feminist named Susan Bordo criticize women who undergo this non-medical plastic surgery for beauty. She criticized that, people don't like to think that they are pawns of astute advertisers or even that they are responding to social norms. Women who have had or are contemplating cosmetic surgery consistently deny the influence of media image. "I'm doing it for me," they insist. But it's hard to account for most of their choices (breast enlargement and liposuction being the most frequently performed operations) outside the context of current cultural norms (Goering).

To be a better person in the social settings is what many people strived to achieve. This led women to try things to show and prove themselves as a part of the society. Selfactualization became a part of everyday struggle for women existentialism in order to achieve happiness. But when the happiness was obtained by manipulating the body, then it can be argued that the concept of happiness itself was also a manipulation. It is unfortunate that people try to achieve comfort within the set of rules dictated by others. When this happens, women lost the privilege of becoming the subject; instead, they became the object to satisfy certain interests.

In deeper statement, Michael Sandel argues that any kind of body enhancement could degrade the humanity. One aspect of our humanity that might be threatened by enhancement and genetic engineering is our capacity to act freely, for ourselves, by our own efforts, and to consider ourselves responsible - worthy of praise or blame - for the thing we do and for the way we are (Sandel).

Sandel add other substantial impact of cosmetic surgery, that it would grow a hyper-agency, a Promethean aspiration to remake nature, including human nature, to serve our purposes and satisfy our desires. The problem is not related to the mechanism but the drive to mastery. And what the drive to mastery misses, and may even destroy, is an appreciation of the gifted character of human powers and achievements (Sandel). Life is a gift; it should be accepted, not to be artificially modified. 


\section{Cosmetics Surgery: Self-Actualization or Manipulation?}

Getting self-improved in any field of life is an effort to survive. Being accepted in social life and getting praised for something good are so much more make sense for a human being. Putting some efforts to maintain the existence in social life is well-known as self-actualization. Then, can we count the cosmetics surgery into a kind of selfactualization? First of all, we have to analyze what a self-actualization should be.

Abraham Maslow (1908-1970) an ultimate thinker in the field of human potential, explain that there are certain characteristics in human being that can count as selfactualization. They are the ones that can accept themselves and others for whoever they are, can put a proper attention to the themselves but have a capability to care for others' needs at the same time, able to give a proper credit to uniqueness of others rather than give such a stereotype judgments, have a capability to make a good relationship with others, can be so much spontaneous and creative, able to say a no to such a compromise and can give a straight position to response the reality (Amzy). What Maslow wanted to underline is a person has the capability to actualize themselves as long as they can accept whoever they are.

Due to the characteristics above, at least there are two distinctions of selfactualization and cosmetics surgery. The first one, self-actualization shared a thought about self-acceptance wholly while cosmetics surgery going on the opposite direction. The drive to master the body through cosmetics surgery means that there is a discontent regarding their own bodies that push them towards the act of fashioning the body. Second, self-actualization wants to encourage the uniqueness and potency that could make a person different, showing their unique self in the society. However, cosmetics surgery precisely makes a person into a mass-human, a person that doesn't have a unique characteristic that is different from others.

Cosmetics surgery can be seen as a self-deception, like a blanket to cover up the lacking within one's self in order to be more acceptable in social life. If we let the phenomena go by without any concern, it will not take long until people fell into a condition where they could not make clear distinction between their nature and their imagination. By then, the phenomena would manipulate the whole existing reality.

\section{CONCLUSION}

Mankind owed themselves in the advancement of science and technology. Through the advancement of technology, the world has become a better place. Two people located in a distant area can communicate with each other, impaired eyes can have their vision repaired, and many dangerous situations can now be circumvented using the right equipment. Science and technology is here to address human needs. That is why technology has been advancing rapidly every time to meet the ever changing needs of the society.

The advancement of science and technology is all good until it refers to human being as its object. Nowadays, the technology is no longer adjusted to human needs, but moreover, the human that have to adjust with the advancement of science and technology. We can conclude that plastic surgery in that term. It was created for help people to manage their body become normal. For instance, a person with harelip who is 
known for having speech disorder. By the advancement of science and technology, they can have the better lips and able to speak clearer than before. Unfortunately, the fact that plastic surgery is capable for changing the look of a person makes many people want to use it for making their body look as perfect as they think. This issue leads us to a question; if the function of science is to humanize the human being, but when that human being becomes its object, is it not a kind of dehumanization?

\section{REFERENCES}

Adian, Donny Gahral. Pengantar Fenomenologi. Penerbit Koekosan, 2010.

Amzy, Nurulfatmi. Kritik Terhadap Pemberdayaan Tubuh Berdasarkan Pemikiran Michael Sandel. University of Indonesia, 2014.

Bostrom, Nick, and Rebecca Roache. "Ethical Issues in Human Enhancement." New Waves in Applied Ethics, edited by Jesper Ryberg, Palgrave Macmillan, 2008, pp. 12052 , http:/ / www.keplersalon.at/barrierefrei/content/download/980/7847/file/Bostrom-Ethical Issues in Human Enhancement.pdf.

Fieser, James, and Bradley Dowden. Internet Encyclopedia of Philosophy. 2011.

Goering, Sara. "The Ethics of Making the Body Beautiful: Lessons from Cosmetic Surgery for a Future of Cosmetic Genetics." The Center of The Study of Ethics in Society, vol. 13, no. 3, 2001, pp. 1-11, https:// scholarworks.wmich.edu/cgi/ viewcontent.cgi?article=1098\&context=ethi cs_papers.

Human Enhancement and The Future of Work. 2012.

Jena, Yeremias. "Kritik Michael Sandel Atas Enhancement Teknologi." Kumpulan Makalah: Etika Ilmu Pengetahuan Dan Kearifan Lokal Nusantara, 2013, pp. 39-59.

Magnis-Suseno, Franz. 13 Model Pendekatan Etika. Kanisius, 2004.

---. Etika Dasar: Masalah-Masalah Pokok Filsafat Moral. Kanisius, 2006.

Menuz, Vincent, et al. "Is Human Enhancement Also a Personal Matter?" Science and Engineering Ethics, vol. 19, no. 1, Springer, 2013, pp. 161-77.

Sandel, Michael J. The Case Against Perfection. Harvard university press, 2007. 